DOI 10.24144/2077-6594.1.2020.196423

УДК 796:616.831-009.11-053.4-085

Кашуба В.О. ${ }^{1}$, Буховець Б.О. ${ }^{2}$

\title{
Сучасні тренди фізичної реабілітації дітей з ДЦП
}

\author{
${ }^{1}$ Національний університет фізичного виховання і спорту України, м. Київ, Україна \\ ${ }^{2}$ Південноукраїнський національний педагогічний університет імені К.Д. Ушинського, м. Одеса, Україна
}

bowena045@gmail.com, kashubavo@gmail.com

\begin{tabular}{cc}
\hline $\begin{array}{c}\text { Кашуба В.А. }{ }^{1}, \text { Буховец Б.О. } \\
\text { Современные тренды }\end{array}$ & $\begin{array}{c}\text { Kashuba V.O. }{ }^{1}, \text { Bukhovets B.O. }{ }^{2} \\
\text { физической реабилитации детей с ДЦП }\end{array}$ \\
$\begin{array}{c}\text { Current trends of physical rehabilitation } \\
\text { of children with cerebral palsy }\end{array}$ \\
${ }^{1}$ иациональний университет физического воспитания & ${ }^{1}$ National university of physical education \\
${ }^{2}$ Южноукраинский национальный педагогический & and sport of Ukraine, Kyiv, Ukraine \\
университет имени К.Д. Ушинського, г. Одесса, Украина & $\begin{array}{c}{ }^{2} \text { South Ukrainian National pedagogical university } \\
\text { named after K.D. Ushynsky, Odesa, Ukraine }\end{array}$
\end{tabular}

\section{Вступ}

Актуальним питанням дитячої неврології $\epsilon$ проблема стрімкого розвитку захворюваності на дитячий церебральний параліч (ДЦП), без тенденції до зниження, як у всьому світі, так і в Україні [1].

Внаслідок ДЦП у більшої частини дітей рухові порушення можуть поєднуватися з психічними, розладами соматичного здоров'я, фізичного розвитку та загальних регуляторних механізмів організму [2]. Більшість науковців підтверджують твердження [3], що фізична реабілітація є основою відновлюваного лікування дітей 3 ДЦП, яка реалізується за допомогою використання засобів фізичної культури, що застосовують рух як основну біологічну функцію організму та забезпечує стимуляцію росту, фізичного розвитку та підтримку гомеостазу. Головним завданням фізичної реабілітації дітей з ДЦП є розвиток моторних можливостей та рухової функції за допомогою комплексного застосування методів фізичної реабілітації [4].

Проблема фізичної реабілітації дітей з ДЦП активно досліджується сучасними вченими всього Світу.

Все вище перераховане та різноманітність клінічної картини форм ДЦП стало підгрунтям для створення сучасних програм 3 комбінацією застосування різних методів фізичної реабілітації, провідним засобом яких $\epsilon$ фізичні вправи, що підтверджується великою кількістю наукових досліджень.

За результатами сучасних наукових досліджень [5], застосування саме лікувальної гімнастики 3 використанням засобів Бобат-терапії у фізичній реабілітації дітей з ДЦП сприяє формуванню рухових навичок та вертикальному пересуванню у просторі.

Незважаючи на науково доведений позитивний досвід застосування засобів Бобат-терапії в фізичній реабілітації дітей з ДЦП, проблема їх використання у багатьох аспектах, ще й досі залишається не вирішеною, а диференціація засобів відповідно до моторних порушень взагалі відсутня [6].

Мета дослідження - обгрунтувати сучасні тренди фізичної реабілітації дітей з ДЦП.

\section{Об’єкт і методи дослідження}

Об’єктом дослідження є процес фізичної реабілітації 3 ДЦП 3 використанням в лікувальній гімнастиці засобів Бобат-терапії.

Методи дослідження: теоретичний аналіз науковометодичної літератури; педагогічні: спостереження, опитування, експеримент (констатувальний та формувальний), тестування («Карткою-тестом оцінки рухових можливостей дітей» за К. і Б. Бобат»); клінічний (неврологічне обстеження з визначенням рівнів моторних порушень за класифікацією великих моторних функцій GMFCS); математична обробка даних [6,7].

\section{Обробка даних}

Теоретичний аналіз науково-методичної літератури реалізовувався за рахунок вивчення сучасних літературних джерел, в яких було висвітлено питання етіології та патогенезу ДЦП, симптоматику, раннє втручання, особливості застосування та диференціацію методів фізичної реабілітації $[6,8]$. Особливу увагу було присвячено дослідження переваг використання в лікувальній гімнастиці саме засобів Бобат-терапії в фізичній реабілітації дітей з ДЦП [1].

Застосування педагогічного експерименту обгрунтовувалось процесом виявлення переваг запропонованої нами програми фізичної реабілітації для дітей хворих на ДЦП з застосуванням засобів Бобаттерапії в лікувальній гімнастиці в умовах спеціалізованого реабілітаційного центру. 
Тестування проводилося 3 метою визначення рухової функції дітей за допомогою «Карти-тесту моторних можливостей» за К. і Б. Бобат, кожен 3 запропонованих тестів оцінювався за 5-бальною шкалою: 0 - неможливість прийняти дану постуру; 1 - пасивний рух за допомогою спеціаліста з фізичної реабілітації; 2 самостійне утримання в заданому положенні; 3 самостійний рух, але абнормальним чином; 4 - рух самостійний, але недосконалий; 5 - нормальний рух $[6,8]$. Так за допомогою даного тесту було охарактеризовано формування рухових навичок: поворот зі спини на бік та живіт, навприсядки з положення стоячи та ін. [1].

Педагогічне та візуальне спостереження $[1,6,8] 3$ обробкою та аналізом результатів дослідження, реалізовували на кожному курсі фізичної реабілітації. Педагогічне спостереження складалось 3 етапного контролю, що проводився для оцінки ефективності 6місячного курсу фізичної реабілітації, для чого діти обстежувались на початку та наприкінці курсу та експресконтролю для оцінки термінового ефекту, де спостерегілась реакція дитини на фізичне навантаження в процесі фізичної реабілітації.

Візуальне спостереження за впливом фізичних навантажень було проведено за рахунок безпосереднього нагляду за дитиною протягом заняття. Окремо спостерігалось за дисциплінованістю, зацікавленістю, емоційністю, зовнішніми проявими перевтомлення (пітливість, забарвлення шкірних покривів, координація рухів, увага та ін.). Завдяки опитуванню дізнавались про загальне самопочуття досліджуваних протягом занять, а також після них [8].

Констатувальний експеримент застосовувався для визначення особливостей стану дітей, що приймали участь у досліджені та отримання вихідного матеріалу для визначення стратегії реалізації програми фізичної реабілітації для дітей з ДЦП та проведення подальшого формувального експерименту. Формувальний експеримент проводили для визначення ефективності запропонованої програми фізичної реабілітації для дітей хворих на ДЦП з застосуванням засобів Бобат-терапії в лікувальній гімнастиці в умовах спеціалізованого реабілітаційного центру в умовах спеціалізованого реабілітаційного центру $[1,9]$.

Клінічний метод дослідження був представлений неврологічним обстеження лікарем-неврологом, у результаті якого було визначено рівні моторних порушень за системою стандартизованої оцінки ступеня затримки моторного розвитку в залежності від їх функціональних можливостей та потреб у додаткових приладах і засобах пересування дітей 3 ДЦП різного віку Gross Motor Functional Classification System (GMFCS) [1].

До 1-го рівня GMFCS відносили дітей, що самостійно сідають, сидять на підлозі та маніпулюють предметом та, як основний спосіб пересування використовують самостійну ходьбу без додаткових засобів пересування. Діти з 2-им рівнем GMFCS могли також сидіти самостійно на підлозі, але мали проблеми 3 рівновагою при маніпулятивній дії з предметом $[6,10]$.
Представники 3-го рівню GMFCS могли також самостійно сидіти на підлозі, але переважно потребували допомоги дорослих.

Розрахунки математичної обробки даних. проводилися на персональному комп'ютері за допомогою програм Біостат, Статистика 6.0 і пакет-аналізу для програми MS Excel 2013, що дозволило провести аналіз вимірювань і розрахунків базових величин [6].

\section{Результати дослідження та їх обговорення}

У констатувальному та формувальному експериментах брали участь 36 дітей хворих на ДЦП 4-х років.

Порівнюючи рухову функцію обраного контингенту «Картою-тестом оцінки моторних можливостей» було зафіксовано 22,46\% досліджуваних, яким вдалося вільно переходити в задане вихідне положення та самостійно утримуватись в ньому. Здійснити перехід у вихідне положення на чотирьох утриматися в ньому та вільно пересуватися змогли незначна кількість дітей 22,3\% (табл. 1).

Серед досліджуваних моторні порушення за системою GMFCS 8,96\% дітей відповідали 1-му рівню GMFCS; 29,85\% - 2-му рівню та 61,19\% - 3-му.

Порівняння показників рухової функції досліджуваних в залежності від рівня GMFCS засвідчило, що до реабілітації між медіанними значеннями дітей 1-го рівня моторної функції виявлено зниження рухової функції за всіма тестовими вправами. При цьому діти з 3-м рівнем GMFCS за всіма тестовими вправами, окрім вправи 3 вихідного положення лежачи на спині, мали нижчі показники рухових можливостей, ніж діти з 2-м рівнем.

Метою розробленої програми було покращити показники рухової функції та скорегувати прояви моторних порушень у дітей хворих на ДЦП. Запропоновану програму фізичної реабілітації від стандартних існуючих відрізняв комплексний підхід до вирішення проблеми фізичної реабілітації дітей хворих на ДЦП $з$ використанням лікувальної гімнастики методом Бобат-терапії.

Побудована програма фізичної реабілітації в умовах в умовах спеціалізованого реабілітаційного центру була розроблена для дітей хворих на ДЦП загальною тривалістю 6 місяців та включала 3 стаціонарних курси по 10 днів та реалізовувалась двух рукових режимах (щадно-тренуючому, тренуючому). За даною програмою проходили фізичну реабілітацію 36 дітей, хворих на ДЦП.

На першому курсі фізичної реабілітації для дітей 1-го, 2-го, 3-го рівнів GMFCS застосовувався щаднотренуючий руховий режим. На подальших курсах фізичної реабілітації для дітей 3 1-им та 2-им рівнем GMFCS використовувався тренуючий руховий режим, а для дітей 3-го рівня зберігався щадно-тренуючий.

Завданням щадно-тренуючого рухового режиму було: сприяння поступово зростаючій загальній адаптації дітей з ДЦП до умов та режиму реабілітаційного центру та збільшенню рівня фізичної підготовленості; знайомство 3 
реабілітаційними заходами; підготовка до поступового збільшення інтенсивності та спектра застосування засобів фізичної реабілітації, їх інтенсивності та тривалості дії; регуляція м'язового тонусу, зменшення впливу патологічних рефлексів на опорно-руховий апарат, профілактика розвитку контрактур та деформацій тощо.

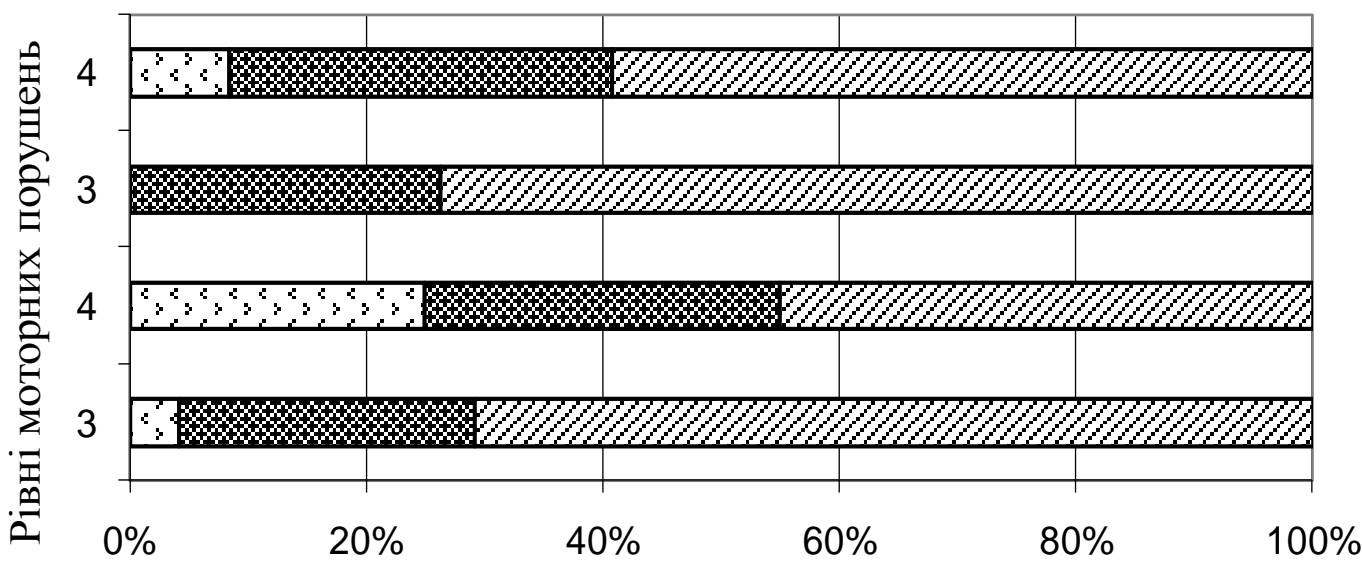

Кількість дітей, \%

3 - 1-ий рівень;

Рис. Розподіл дітей, хворих на ДЦП, за рівнями моторних порушень відповідно до системи GMFCS (n = 134)

Таблиця 1. Аналіз залежності показників рухової функції від рівня моторних порушень дітей до курсу фізичної реабілітації $(n=36)$

\begin{tabular}{|c|c|c|c|c|c|c|c|c|c|}
\hline \multirow{3}{*}{ Показник } & \multicolumn{9}{|c|}{ Рівень GMFCS } \\
\hline & \multicolumn{3}{|c|}{$1-\grave{n}, n=3$} & \multicolumn{3}{|c|}{ 2-й, n = 14} & \multicolumn{3}{|c|}{ 3-й, n = 19} \\
\hline & Me & $25 \%$ & $75 \%$ & Me & $25 \%$ & $75 \%$ & Me & $25 \%$ & $75 \%$ \\
\hline Лежачи на спині & 5,0 & 5,0 & 5,0 & 4,5 & 4,0 & 5,0 & 4,0 & 4,0 & 4,0 \\
\hline Лежачи на животі & 5,0 & 5,0 & 5,0 & 4,0 & 4,0 & 5,0 & 4,0 & 4,0 & 4,0 \\
\hline Поворот убік & 5,0 & 4,0 & 5,0 & 4,0 & 4,0 & 5,0 & 4,0 & 3,0 & 4,0 \\
\hline Поворот на живіт & 5,0 & 4,0 & 5,0 & 4,0 & 4,0 & 4,0 & 3,0 & 3,0 & 4,0 \\
\hline Сидячи & 5,0 & 4,0 & 5,0 & 4,0 & 4,0 & 4,0 & 3,0 & 3,0 & 4,0 \\
\hline На колінах & 5,0 & 4,0 & 5,0 & 4,0 & 3,0 & 5,0 & 3,0 & 3,0 & 3,0 \\
\hline Навприсядки & 5,0 & 3,0 & 5,0 & 4,0 & 3,0 & 4,0 & 3,0 & 3,0 & 3,0 \\
\hline Стоячи & 4,0 & 3,0 & 5,0 & 4,0 & 3,0 & 4,0 & 3,0 & 2,0 & 3,0 \\
\hline
\end{tabular}

Тренуючий руховий режим застосовувався для: зменшення впливу патологічних рефлексів на опорноруховий апарат, корекція контрактур та деформацій, навчання самообслуговуванню та догляду за дитиною 3 особливими потребами, формування рухових навичок, зміцнення м'язів спини і тулуба, закріплення досвіду рухової активності, розвиток фізичних якостей.

Розроблена програма фізичної реабілітації складалась 3 2-х компонентів: базового та варіативного. У базовому компоненті застосовувались методи фізичної реабілітації (апаратна фізіотерапія, сенсорна інтеграція, кінезіотейпування). У варіативному компоненті використовувалась лікувальна гімнастика з застосуванням засобів Бобат-терапії (фізичні вправи, навчання навичкам самообслуговування та догляду за дитиною, лікування положенням.
В залежності від індивідуальних можливостей пацієнтів, а саме рівнів моторних порушень за системою GMFCS, було створено комплекси фізичних вправ, в основі яких були диференційовані засоби Бобат-терапії у процедурі лікувальної гімнастики). В запропонованій програмі фізичної реабілітації у процедурі лікувальної гімнастики використовувавали засоби Бобат-терапії, що послідовно ускладнювали, у комбінації 3 іграми i дихальними вправами відповідно до рівнів GMFCS.

Так дітям 3 найнижчим 3-ім рівнем моторних порушень, використовували засоби Бобат-терапії, які були об'єднані у комплекси лікувальної гімнастики, в яких застосовувались дихальні вправи та ігри в залежності від функціональних можливостей опорно-рухового апарату. Діти з більш високим 2-им рівнем моторних порушень, виконували більш складні у застосуванні засоби 
Бобат-терапії, а також дихальні вправи та ігри, що також були об'єднані в окремі комплекси. Найскладніші вправи, об'єднані у відповідні комплекси, застосовували діти 3 1-им рівнем моторних порушень.

Лікувальна гімнастика 3 застосуванням засобів Бобат-терапії будувалися за стандартною схемою: вступна, основна, заключна частини. Вступна частина включала фізичні вправи 3 малим навантаженням для дрібних і середніх м'язових груп у вихідному положенні лежачи на спині профілактичного та загальнопідготовчого характеру, дихальні вправи, лікування положенням, ігри та передбачала поступову адаптацію дитини до навантаження, яке зростало.

Основна частина поєднувала елементи загального та спеціального тренування. Поставлені завдання вирішувались за допомогою коригувальних вправ у вихідних положеннях лежачи на животі, боках, сидячи, на чотирьох, стоячи; дихальними вправами; навчанням самообслуговування та догляду за особливою дитиною, іграми. У першій половині основної частини застосовувались фізичні вправи, що вже були знайомі пацієнтам, а у другій - виконувались нові вправи.

В заключній частині зниження фізичного навантаження реалізовувалось за рахунок використання дихальних вправ та фізичних вправ у вихідних положеннях сидячи та стоячи на колінах, що виконувались у повільному темпі та з невеликою кількістю повторень.

Результати обстежень дітей після проходження курсу фізичної реабілітації за досліджуваними показниками показали, що в порівнянні з початковими даними до курсу фізичної реабілітації (табл. 1) розподіли дітей за рівнями сформованості рухових функцій не мали статистично значущих відмінностей ( $>>0,05)$. Після курсу фізичної реабілітації відмінності між досліджуваними показниками носили більш явний характер і мали статично значущі відмінності $(\mathrm{p}<0,05)$ (табл. 2$)$.

Так, показники дітей у вихідному положенні лежачи на спині збільшились 8,70\%, лежачи на животі - на 9,51\%, сидячи - на $10,10 \%$, на колінах - на $12,73 \%$, навприсядки на $13,22 \%$, стоячи - на $15,95 \%$ та здатності здійснювати поворот у бік - на 6,38\%, а на живіт - на 7,14\%.

Після курсу фізичної реабілітації у дітей було констатовано позитивні зрушення рівнів моторних порушень, що доводить збільшення кількості дітей, віднесених до 1-го рівня GMFCS, що зросла на 47,22\%, за рахунок зменшення кількості дітей 3 2-им рівнем на $38,89 \%$ та дітей 3 3-ім рівнем на 8,57\%. Відповідно $38,89 \%$ з рівня 3 перейшли на 2-й рівень.

Після курсу фізичної реабілітації у дітей було зафіксовано збереження тенденції до знижених показників рухової функції при низькому рівні моторних порушень (табл. 3). В ході дослідження було припущено, що низькі показники рухової функції були обумовлені відповідно низьким рівнем GMFCS у дітей з ДЦП у формі спастичної диплегії.

Спираючись на дані отримані в ході дослідження, можливо припустити, що низькі показники рухової функції обумовлені відповідно низьким рівнем GMFCS у дітей 4-х років хворих на ДЦП.

\section{Таблиця 2. Показники рухової функції дітей до та після курсу фізичної реабілітації $(\mathbf{n}=36)$}

\begin{tabular}{|c|c|c|c|c|c|c|}
\hline \multirow{2}{*}{\multicolumn{2}{|c|}{ Показник }} & \multicolumn{5}{|c|}{ Середньостатистичні показники, бал } \\
\hline & & \multicolumn{4}{|c|}{$\mathrm{n}=36$} & \multirow{3}{*}{$\mathbf{S}$} \\
\hline & & \multirow{2}{*}{$\begin{array}{c}\bar{x} \\
38,89\end{array}$} & \multirow{2}{*}{$\begin{array}{c}\text { Me } \\
55,56\end{array}$} & \multirow{2}{*}{$\begin{array}{l}25 \% \\
2,78\end{array}$} & \multirow{2}{*}{$\begin{array}{c}75 \% \\
-\end{array}$} & \\
\hline Лежачи на спині & До & & & & & \\
\hline & Після & $75,0 *$ & $25,0 *$ & - & - & - \\
\hline \multirow[t]{2}{*}{ Лежачи на животі } & До & 30,56 & 61,11 & 5,56 & - & - \\
\hline & Після & $72,22 *$ & $27,78^{*}$ & - & - & - \\
\hline \multirow[t]{2}{*}{ Поворот у бік } & До & 30,56 & 61,11 & 5,56 & - & - \\
\hline & Після & $55,56^{*}$ & 38,89 & 5,56 & - & - \\
\hline \multirow[t]{2}{*}{ Поворот на живіт } & До & 16,67 & 52,78 & 30,56 & - & - \\
\hline & Після & $55,56^{*}$ & $38,89 *$ & 5,56 & - & - \\
\hline \multirow[t]{2}{*}{ Сидячи } & До & 13,89 & 38,89 & 47,22 & - & - \\
\hline & Після & 33,33 & 58,33 & $8,33^{*}$ & - & - \\
\hline \multirow[t]{2}{*}{ На колінах } & До & 19,44 & 22,22 & 58,33 & - & - \\
\hline & Після & 36,11 & 52,78 & 11,11 & - & - \\
\hline \multirow[t]{2}{*}{ Навприсядки } & До & 8,33 & 25,0 & 58,33 & 8,33 & - \\
\hline & Після & 33,33 & 44,44 & 22,22 & - & - \\
\hline \multirow[t]{2}{*}{ Стоячи } & До & 5,56 & 27,78 & 50,0 & 13,89 & 2,78 \\
\hline & Після & 13,89 & 50,0 & 36,11 & - & - \\
\hline
\end{tabular}

Примітка: * - p<0,05 при перевірці статистично значущості відмінностей частки дітей до експерименту, що відносяться до відповідного рівня розвитку рухової функції, порівняно з даними після дослідження. 
Таблиця 3. Аналіз залежності показників рухової функції від рівня моторних порушень дітей після курсу фізичної реабілітації (n = 36)

\begin{tabular}{|c|c|c|c|c|c|c|c|c|c|}
\hline \multirow{3}{*}{ Показник } & \multicolumn{9}{|c|}{ Рівні GMFCS } \\
\hline & \multicolumn{3}{|c|}{$1(n=20)$} & \multicolumn{3}{|c|}{$2(n=14)$} & \multicolumn{3}{|c|}{$3(n=2)$} \\
\hline & Me & $25 \%$ & $75 \%$ & Me & $25 \%$ & $75 \%$ & Me & $25 \%$ & $\mathbf{7 5 \%}$ \\
\hline Лежачи на спині & 5,0 & 5,0 & 5,0 & 5,0 & 4,0 & 5,0 & 4,0 & 4,0 & 4,0 \\
\hline Лежачи на животі & 5,0 & 5,0 & 5,0 & 5,0 & 4,0 & 5,0 & 4,0 & 4,0 & 4,0 \\
\hline Поворот убік & 5,0 & 4,0 & 5,0 & 4,0 & 4,0 & 5,0 & 3,5 & 3,0 & 4,0 \\
\hline Поворот на живіт & 5,0 & 4,5 & 5,0 & 4,0 & 4,0 & 5,0 & 3,5 & 3,0 & 4,0 \\
\hline Сидячи & 4,5 & 4,0 & 5,0 & 4,0 & 4,0 & 4,0 & 3,0 & 3,0 & 3,0 \\
\hline На колінах & 5,0 & 4,0 & 5,0 & 4,0 & 4,0 & 4,0 & 3,0 & 3,0 & 3,0 \\
\hline Навприсядки & 5,0 & 4,0 & 5,0 & 4,0 & 3,0 & 4,0 & 3,0 & 3,0 & 3,0 \\
\hline Стоячи & 4,0 & 4,0 & 4,5 & 3,0 & 3,0 & 3,0 & 3,0 & 3,0 & 3,0 \\
\hline
\end{tabular}

Перспективи подальших досліджень полягають у подальшому дослідженні ефективності впливу лікувальної гімнастики 3 застосування засобів Бобаттерапії дітям с синдромом рухових порушень.

\section{Висновки}

Аналіз наукової літератури свідчить, що проблема фізичної реабілітації дітей з ДЦП є актуальною темою дослідження, незважаючи на великий інтерес науковців та отримані до теперішнього часу результати дискусій. Науковці стверджують, що провідною у комплексі реабілітаційних заходів $\epsilon$ фізична реабілітація, яка базується на диференційованому застосуванні засобів фізичної культури $[5,11]$.

Серед традиційних методів фізичної реабілітації для дітей з ДЦП, за результатами сучасних досліджень, виділяється Бобат-терапія, що $є$ визнаним ефективним підходом науковцями всього світу [8].
Розроблена програми фізичної реабілітації для дітей хворих на ДЦП в умовах спеціалізованого реабілітаційного центру, що базувалась на застосуванні засобів Бобат-терапії в процедурі лікувальної гімнастики успішно апробовано під час формувального експерименту: іiі ефективність доводять кількісні зміни (на рівні $\mathrm{p}<0,05$ ) досліджуваних показників.

За статистичною обробкою даних після курсу фізичної реабілітації частка дітей віднесених до 1-го рівня GMFCS (найсприятливішого), виявилася статистично значуще більшою $(\mathrm{p}<0,05)$ порівняно 3 досліджуваними показниками до курсу.

На основі узагальнення одержаних даних доведено ефективність реалізації та раціональну спрямованість впровадженої програми, що засвідчують позитивні зміни рухової функції та корекція проявів моторних порушень дітей хворих на ДЦП.

\section{Література}

1. Bukhovets BO. Control psychophysical children's development under the correction movement disorder. Journal of Education, Health and Sport. 2016;6(2):200-10.

2. Himmelmann K, Uvebrant P. Function and neuroimaging in cerebral palsy: a population-based study. Dev Med Child Neurol. 2011;53(6):516.

3. Jan MMS. Cerebral Palsy: Comprehensive Review and Update. Ann Saudi Med. 2006;26(2):123-32.

4. Kamen G, Patten C, CD Du, Sison S. An accelerometry-based system for the assessment of balance and postural sway. Gerontology. 1998;44(1):40-50.

5. Bobath K. The motor deficit in patients with Cerebral Palsy. Suffolk: The Lavenham Press LTD; 1966. p. 13-25.

6. Kashuba V, Bukhovets B. The indicators of physical development of children with Cerebral Palsy as the basis of differential approach to implementation of the physical rehabilitation program of using Bobath-therapy method. Journal of Education, Health and Sport for merly Journal of Health Sciences. Kazimierz Wielki University in Bydgoszcz. 2017;7(3):835-49.

7. Himmelmann K, Lindh K, Hidecker MJ. Communication ability in cerebral palsy: a study from the CP register of western Sweden. Eur J Paediatr Neurol. 2013;17(6):568-74.

8. Bobath $K$. The problem of spastically in the treatment of patients with lesions of the upper motor neuron. London: Cerebral Palsy Centre; 1969. p. 459-64.

9. Bobath K. The normal postural reflex mechanism and its deviationin children with cerebral palsy. Physiotherapy. 1971;(57):515-25.

10. Bobath K, Bobath B. The neuro-developmental treatment. In: Scrutton D, eds. Management of the motor disordersof children with cerebral palsy. Philadephia: JB Lippincott; 1984. p. 6-18. 


\section{References}

1. Bukhovets BO. Control psychophysical children's development under the correction movement disorder. Journal of Education, Health and Sport. 2016;6(2):200-10.

2. Himmelmann K, Uvebrant P. Function and neuroimaging in cerebral palsy: a population-based study. Dev Med Child Neurol. 2011;53(6):516.

3. Jan MMS. Cerebral Palsy: Comprehensive Review and Update. Ann Saudi Med. 2006;26(2):123-32.

4. Kamen G, Patten C, CD Du, Sison S. An accelerometry-based system for the assessment of balance and postural sway. Gerontology. 1998;44(1):40-50.

5. Bobath K. The motor deficit in patients with Cerebral Palsy. Suffolk: The Lavenham Press LTD; 1966. p. 13-25.

6. Kashuba V, Bukhovets B. The indicators of physical development of children with Cerebral Palsy as the basis of differential approach to implementation of the physical rehabilitation program of using Bobath-therapy method. Journal of Education, Health and Sport for merly Journal of Health Sciences. Kazimierz Wielki University in Bydgoszcz. 2017;7(3):835-49.

7. Himmelmann K, Lindh K, Hidecker MJ. Communication ability in cerebral palsy: a study from the CP register of western Sweden. Eur J Paediatr Neurol. 2013;17(6):568-74.

8. Bobath $\mathrm{K}$. The problem of spastically in the treatment of patients with lesions of the upper motor neuron. London: Cerebral Palsy Centre; 1969. p. 459-64.

9. Bobath K. The normal postural reflex mechanism and its deviationin children with cerebral palsy. Physiotherapy. 1971;(57):515-25.

10. Bobath K, Bobath B. The neuro-developmental treatment. In: Scrutton D, eds. Management of the motor disordersof children with cerebral palsy. Philadephia: JB Lippincott; 1984. p. 6-18.

Дата надходження рукопису до редакції: 09.01.2020 р.

За результатами сучасних наукових досліджень, застосування саме лікувальної гімнастики 3 використанням засобів Бобат-терапії у фізичній реабілітації дітей з ДЦП сприяє формуванню рухових навичок та вертикальному пересуванню у просторі.

Мета дослідження - обгрунтувати сучасні тренди фізичної реабілітації дітей з ДЦП.

Матеріали та методи дослідження. Аналіз науково-методичної літератури; педагогічні: спостереження, опитування, експеримент (констатувальний та формувальний), тестування («Карткою-тестом оцінки рухових можливостей дітей» за К. і Б. Бобат); клінічний (неврологічне обстеження з визначенням рівнів моторних порушень за класифікацією GMFCS); математична обробка даних.

Розроблена програми фізичної реабілітації для дітей хворих на ДЦП в умовах спеціалізованого реабілітаційного центру, що базувалась на застосуванні засобів Бобат-терапії в процедурі лікувальної гімнастики успішно апробовано під час формувального експерименту: їі ефективність доводять кількісні зміни (на рівні р<0,05) досліджуваних показників.

Висновки. На основі узагальнення одержаних даних доведено ефективність реалізації та раціональну спрямованість впровадженої програми, що засвідчують позитивні зміни рухової функції та корекція проявів моторних порушень дітей хворих на ДЦП.

Ключові слова: Бобат-терапія, лікувальна гімнастика, фізична реабілітація.

По результатам современных научных исследований, применение именно лечебной гимнастики с использованием средств Бобат-терапии в физической реабилитации детей с ДЦП способствует формированию двигательных навыков и вертикальному передвижению в пространстве.

Цель исследования - обосновать современные тренды физической реабилитации детей с ДЦП.

Материалы и методы исследования. Анализ научно-методической литературы; педагогические: наблюдение, опрос, эксперимент (констатирующий и формирующий), тестирование («Карте-тестом оценки двигательных возможностей детей» по К. и Б. Бобат); клинический (неврологическое обследование с определением уровней моторных нарушений по классификации GMFCS); математическая обработка данных.

Разработанная программы физической реабилитации для детей больных ДЦП в условиях специализированного реабилитационного центра, основана на применении средств Бобат-терапии в процедуре лечебной гимнастики успешно апробирован во время формирующего эксперимента: её эффективность доказывают количественные изменения (на уровне $\mathbf{p}<0,05)$ исследуемых показателей .

Выводы. На основе обобщения полученных данных доказана эффективность реализации и рациональную направленность внедренной программы, удостоверяющих положительные изменения двигательной функции и коррекция проявлений моторных нарушений детей больных ДЦП.

Ключевые слова: Бобат-терапия, лечебная гимнастика, физическая реабилитация. 
According to the results of modern scientific studies, the use of therapeutic gymnastics with the use of Bobat therapy in the physical rehabilitation of children with cerebral palsy promotes the formation of motor skills and vertical movement in space.

The purpose of the study is to substantiate current trends in physical rehabilitation of children with cerebral palsy.

Materials and methods of research. Analysis of scientific and methodological literature; pedagogical: observation, interrogation, experiment (ascertaining and forming), testing ("Map-test of assessment of children's motor abilities" by K. and B. Bobat); clinical (neurological examination to determine the levels of motor disorders according to the GMFCS classification) mathematical data processing.

The developed programs of physical rehabilitation for children with cerebral palsy in the conditions of a specialized rehabilitation center, based on the use of Bobat therapy in the procedure of therapeutic gymnastics successfully tested during the formative experiment: its effectiveness is proved by quantitative changes (at the level of $\mathrm{p}<0.05$ ) of the studied indicators.

Conclusions. On the basis of generalization of the received data the efficiency of realization and rational orientation of the implemented program are proved, certifying the positive changes of motor function and correction of manifestations of motor disorders of children of patients with cerebral palsy.

Key words: Bobat therapy, medical gymnastics, physical rehabilitation.

Конфлікт інтересів: відсутній.

Conflicts of interest: authors have no conflicts of interest to declare.

\section{Відомості про авторів}

Кашуба Віталій Олександрович - доктор наук з фізичного виховання та спорту, професор, Національний університет фізичного виховання і спорту України; м. Київ, Україна. +380 (97) 555-54-43, kashubavo@ gmail.com, ORCID 0000-0001-6669-738X.

Буховець Божена Олегівна - кандидат наук 3 фізичного виховання та спорту, викладач кафедри гімнастики та спортивних єдиноборств Південноукраїнського національного педагогічного університету імені К.Д. Ушинського; м. Одеса, Україна.

bowena045@gmail.com, ORCID 0000-0003-2386-3995. 